\title{
PERTIMBANGAN HAKIM TERHADAP PENETAPAN DISPENSASI PERKAWINAN DI PENGADILAN AGAMA KOTA SUKABUMI TAHUN 2019
}

\author{
Saida Nurfadila Iswandi \\ snurfadila@gmail.com \\ Universitas Muhammadiyah Sukabumi
}

\begin{abstract}
This article aims to describe the Judge's Consideration of the Determination of Marriage Dispensation at the Sukabumi City Religious Court in 2019. One of the requirements for marriage is the minimum age limit in accordance with Article 7 paragraph (1) of Law No. 16 of 2019 which states that "marriage is only permitted if men and women have reached the age of 19 (nineteen) years ". The method used is a qualitative approach method using a normative juridical research approach. This research examines the basis on what is used by the judge in granting permission for dispensation of marriage. The results of this study explain that the Judge uses PERMA Number 5 of 2019 concerning Guidelines for Adjudicating Marriage Dispensation Applications as a basis in deciding and granting cases of marriage dispensation. There are several forms of determination regarding the dispensation of marriage in the Sukabumi religious court, including the dispensation given to prospective brides whose age is still below the minimum age to have a marriage, dispensations given to prospective grooms whose age is still below the minimum age to have a marriage, granting marriage dispensation to underage women who are already pregnant, refusing or not being granted a marriage dispensation request. The positive contribution expected from this article is the dedication of the community to the minimum age limit for marrying with the aim of forming a harmonious and quality family.
\end{abstract}

Keywords: Marriage, Dispensation, Judge

\begin{abstract}
Abstrak
Artikel ini bertujuan untuk mendeskripsikan Pertimbangan Hakim Terhadap Penetapan Dispensasi Perkawinan di Pengadilan Agama Kota Sukabumi Tahun 2019. Salah satu persyaratan pernikahan adalah batasan usia minimal sesuai Pasal 7 ayat (1) Undang-Undang No.16 Tahun 2019 yang menyatakan bahwa "perkawinan hanya diizinkan apabila pria dan wanita sudah mencapai umur 19 (Sembilan belas) tahun”. Metode yang digunakan
\end{abstract}


adalah metode pendekatan Kualitatif dengan menggunakan pendekatan penelitian Yuridis Normatif. Penelitian ini meneliti tentang landasan apa yang dijadikan oleh hakim dalam memberikan izin dispensasi perkawinan. Hasil penelitian ini menjelaskan bahwa Hakim menggunakan PERMA Nomor 5 tahun 2019 tentang Pedoman Mengadili Permohonan Dispensasi Kawin sebagai landasan dalam memutus dan mengabulkan perkara dispensasi perkawinan. Terdapat beberapa bentuk penetapan mengenai dispensasi perkawinan di pengadilan agama sukabumi, diantaranya yaitu dispensasi yang diberikan kepada calon mempelai wanita yang umurnya masih di bawah batas minimum untuk melangsungkan perkawinan, dispensasi yang diberikan kepada calon mempelai pria yang umurnya masih di bawah batas minimum usia untuk melangsungkan perkawinan, pemberian dispensasi perkawinan kepada perempuan di bawah umur yang sudah hamil, penolakan atau tidak dikabulkannya suatu permohonan dispensasi perkawinan. Kontribusi positif yang diharapkan dari artikel ini ialah teredukasinya masyarakat terhadap batas usia minimal untuk melangsungkan perkawinan dengan tujuan membentuk keluarga yang harmonis dan berkualitas.

\section{Kata Kunci: Pernikahan, Dispensasi, Hakim}

\section{A. Pendahuluan}

Definisi dispensasi menurut Kamus Besar Bahasa Indonesia yaitu pengecualian dari aturan umum untuk keadaan yang khusus, pembebasan dari suatu kewajiban atau larangan. ${ }^{1}$ Dispensasi juga dapat disebut dengan izin pembebasan dari suatu kewajiban, atau suatu upaya kelonggaran waktu atau suatu keringanan hal dalam kasus tertentu pada Undang-undang. Selanjutnya disimpulkan bahwa dispensasi perkawinan adalah keringanan yang diberikan Undang-undang untuk memberikan izin pada anak di bawah umur melalui Pengadilan Agama untuk melangsungkan perkawinan.

Dispensasi perkawinan merupakan salah satu ranah Hukum Perdata yaitu masuk ke dalam hal perkawinan. Sehingga permohonannya diajukan kepada Pengadilan Agama yang memiliki kewenangan menerima, memutus, dan menyelesaikan perkara-perkara bagi orang-orang yang beragama Islam. Permohonan tersebut dapat dikabulkan maupun ditolak, sesuai dengan

${ }^{1}$ Kamus Besar Bahasa Indonesia, ke-lima (Bahan Pengembangan Bahasa, Kementerian Pendidikan dan Kebudayaan Republik Indonesia, 2016). Hlm.23 
pertimbangan dan keyakinan Hakim yang telah diberi kewenangan untuk mengadili perkara tersebut. Setelah adanya Undang-Undang No.16 Tahun 2019 tentang Perubahan Atas Undang-Undang No.1 Tahun 1974, di Pengadilan Agama Kota Sukabumi ini semakin banyak yang mendaftar untuk mengajukan agar mendapatkan dispensasi perkawinan.

Pernikahan di bawah umur setidaknya memiliki beberapa dampak negatif yang ditimbulkan, dan tidak jarang juga menimbulkan permasalahan baru. Pertama, pernikahan di bawah umur merupakan salah satu penyebab dari tingginya angka perceraian. Hal ini dikarenakan anak-anak tersebut belum matang secara fisik, mental dan spiritual untuk mengemban tanggung jawab yang diperlukan dalam mempertahankan pernikahan. Kedua, pernikahan di bawah umur bisa menyebabkan Kekerasan Dalam Rumah Tangga (KDRT) selain karna ketimpangan relasi kuasa, para pengantin muda cenderung penuh emosi sehingga gampang tersulut emosi. Ketiga, akan naiknya angka kemiskinan di Indonesia, karena biasanya pernikahan di bawah umur sangat rentan terhadap kemiskinan karena secara ekonomi mereka belum siap bekerja. Lalu masalah lainnya yang tidak kalah penting yaitu pernikahan di bawah umur menyebabkan berbagai isu dan permasalahan kesehatan. Tingginya AKI (Angka Kematian Ibu) setalah melahirkan disebabkan karena ketidaksiapan fungsi-fungsi reproduksi ibu secara biologis dan psikologis. Selain kesehatan ibu, angkat kematian bayi bagi ibu remaja juga lebih tinggi dan kebanyakan bayi lahir dari ibu berusia remaja di bawah 17 tahun terlahir secara premature. Kemungkinan anak-anak tersebut mengalami hambatan pertumbuhan (stunting).

Maka dari itu, kebijaksanaan dan kehati-hatian dari pihak pengadilan agama sangat berperan penting dalam menetapkan permohonan dispensasi perkawinan baik dalam mengabulkan maupun menolak dengan disertai alasan yang kuat, sehingga jumlah angka permohonan dispensasi bisa ditekan. Berdasarkan data yang diperoleh dalam SIPP (Sistem Informasi Penelusuran Perkara) Pengadilam Agama Kota Sukabumi per-tanggal 4 Desember 2019 sampai dengan tanggal 18 Maret 2020 jumlah perkara pengajuan dispensasi 
perkawinan berjumlah 41 perkara. Dari sebanyak 41 perkara tersebut, 37 perkara dikabulkan oleh hakim untuk pemberian dispensasi perkawinan, dan empat perkara lainnya dalam proses persidangan.

\section{B. Pembahasan}

1) Kajian Teori

Dalam penelitian ini teori yang digunakan yaitu teori Perlindungan Hukum, dengan alasan bahwa hukum melindungi kepentingan seseorang dengan cara mengalokasikan kekuasaannya kepadanya, untuk bertindak dalam rangka kepentingannya, dan kepentingan itu merupakan sasaran hak. Perlindungan hukum yang ditempuh melalui suatu legislasi memiliki asas hukum yang mendasarinya. Demikian pula perlindungan hukum yang ditempuh melalui upaya pembuatan dan pencantuman langkah-langkah melalui legislasi yang memiliki tujuan, ruang lingkup direncanakan melalui strategi kebijakan.

Teori yang selanjutnya digunakan dalam penelitian ini adalah teori Maslahah Mursalah. Asas kemanfaat dalam islam adalah asas yang menyertai asas kepastian dan kepastian hukum, yaitu segala pengambilan keputusan yang ditimbang dan didasarkan pada manfaat dan maslahat tidaknya suatu keputusan tersebut. Dalam maksud realistisnya, mashlahah (Indonesia:maslahat) sebagai lawan dari mafsadat yang berarti sebab, cara atau suatu tujuan yang baik. Maslahah juga berarti suatu permasalahan atau bagian dari suatu urusan yang menghasilkan suatu kebaikan, dan juga kemanfaatan. $^{2}$

Menurut alghazali, mashlahah yang sebagaimana disebutkan di atas adalah suatu pernyataan dengan tujuan untuk mencari suatu kemanfaatan dan menolak segala sesuatu yang madharat, karena mencari suatu kemanfaatan dan menolak kemudharatan merupakan maksud dan tujuan dari semua makhluk (maqashid al-khalq). Menurut alghazali,

${ }^{2}$ Mukhsin Nyak Umar, Rekonstruksi Pemikiran Hukum Islam Di Indonesia (Banda Aceh: Yayasan PeNA, 2006). 
kemaslahatan juga merupakan segala maksud (obyektif) hukum syar'a yang meliputi 5 aspek yaitu proteksi terhadap agama, akal, jiwa, keturunan dan harta. ${ }^{3}$ Maka, segala sesuatu yang menjamin dalam kelima aspek tersebut adalah maslahat, sedang yang menganggu ke lima aspe tersebut adalah mafsadah. ${ }^{4}$

2) Metode penelitian

Jenis penelitian ini adalah penelitian lapangan (field research). Penelitian ini mengambil data primer dari lapangan yang dikaji secara intensif yang disertai analisa dan pengujian kembali pada semua data atau informasi yang telah didapat dan kemudian dikumpulkan. Dilihat dari sisi pelaksanaannya, penelitian secara langsung berinteraksi dengan Hakim Pengadilan Agama Kota Sukabumi untuk mendapatkan data pertimbangan Hakim terkait penetapan dispensasi perkawinan pada tahun 2019. Maka dapat dikatakan bahwa penelitian ini menggunakan metode pendekatan Kualitatif, penelitian Kualitatif ini adalah prosedur penelitian yang menghasilkan data deskriptif berupa kata-kata tulisan atau lisan dari orangorang dan perilaku yang diamati.

3) Hasil Penelitian

Sebagaimana yang kita ketahui dalam Pasal 10 ayat (1) Undangundang Nomor 48 tahun 2009 tentang kekuasaan kehakiman, pada pasal tersebut disebutkan bahwa dalam memeriksa, mengadili, memutus suatu perkara pengadilan dilarang untuk menolak atas segala perkara yang diajukan, dengan segala dalil hukumnya yang mengatur tidak ada atau kurang jelas, dalam artian lain maka pengadilan wajib untuk memeriksa dan mengadilinya. Pengadilan agama adalah salah satu penyelenggara kekuasaan kehakiman dengan tugas pokok seperti yang telah disebutkan pada Pasal 10 ayat (1) Undang-undang Nomor 48 tahun 2009.

Terlebih dalam perkara penetapan dispensasi perkawinan ini telah ada dasar hukum yang jelas, termasuk keputusan-keputusan apa saja yang

\footnotetext{
${ }^{3}$ Mukhsin Nyak Umar, Rekonstruksi Pemikiran Hukum Islam Di Indonesia.., Hlm.14
}

${ }^{4}$ Ibid. 
harus hakim pertimbangkan. Jika dilihat dalam pengabulan perkara dispensasi perkawinan ini, hakim pengadilan agama sukabumi mengabulkan hampir semua permohonan yang masuk, bisa dikatakan hampir 90\% perkara dispensasi perkawinan yang terdaftar dan diadili di pengadilan agama sukabumi mendapatkan pengabulan dan izin untuk melangsungkan perkawinan dari hakim. Tentunya dalam memutus dan mengabulkan perkara ini hakim memiliki sebuah landasan dan alasan apa saja yang dijadikan rujukan untuk memberikan izin dispensasi perkawinan kepada para pemohon.

Dispensasi diberikan sebagai suatu pengecualian bagi salah satu atau kedua mempelai baik laki-laki maupun perempuan yang akan melaksanakan perkawinan dengan umur yang belum mencapai batasan terendah dalam Undang-undang perkawinan, tentunya dispensasi ini memiliki syarat-syarat serta prosedur yang telah berlaku. Yaitu sebagai berikut: ${ }^{5}$

a. Kedua orang tua (ayah dan ibu) calon mempelai yang masih di bawah umur, yang masing-masing sebagai pemohon 1 dan pemohon 2, mengajukan permohonan dalam bentuk secara tertulis ke Pengadilan Agama.

b. Permohonan diajukan ke Pengadilan Agama di tempat tinggal para pemohon.

c. Permohonan tersebut harus memuat: 1) identitas para pihak (Ayah sebagai pemohon 1 dan Ibu sebagai pemohon 2; 2) Posita (alasanalasaan atau dalil yang mendasari diajukannya permohonan tersebut dengan dilengkapi identitas para calon mempelai; dan 3) Petitum (hal yang dimohon putusannya dari pengadilan).

Dalam memutus dan mengabulkan perkara mengenai dispensasi perkawinan ini hakim menjadikan PERMA Nomor 5 Tahun 2019 tentang

${ }^{5}$ Amran Suadi, Aspek Perlindungan Anak Indonesia: Analisis Tentang Perkawinan di Bawah Umur (Jakarta, 2018). Hlm. 19 
Pedoman Mengadili Permohonan Dispensasi Kawin (selanjutnya akan disebut PERMA).

4) Pembahasan Penelitian

Dengan merujuk kepada PERMA tersebut tentunya hakim tidak semena-mena dan tidak melampaui koridor-koridor yang sudah ditetapkan dalam PERMA tersebut dalam memutus dan mengadili perkara dispensasi perkawinan ini. Dalam BAB II Pasal 2 PERMA tersebut, disebutkan bahwa dalam mengadili permohononan dispensasi perkawinan hakim mendasar kepada asas:

a. Kepentingan terbaik bagi anak;

b. Hak hidup dan tumbuh kembang anak;

c. Penghargaan atas pendapat anak;

d. Penghargaan atas harkat dan martabat manusia;

e. Non-diskriminasi;

f. Kesetaraan gender;

g. Persamaan di depan hukum

h. Keadilan;

i. Kemanfaatan, dan;

j. Kepastian hukum.

Berdasarkan semua poin diatas yang disebutkan dan yang tercantum pada PERMA, hakim dalam memutus tentunya memperhatikan poin-poin tersebut apakah dalam poin-poin tersebut ada yang salah satunya bertentangan dengan alasan para pemohon untuk mengajukan permohonan dispensasi perkawinan tersebut. Ketika persidangan dilaksankan, tentunya hakim menghadirkan para pemohon, atau bisa dikatakan orang tua atau wali calon mempelai yang hendak melangsungkan perkawinan. Tidak hanya menghadirkan para pemohon, hakim juga menghadirkan calon 
mempelai, baik calon mempelai pria dan juga calon mempelai wanita. Seperti yang tercantum dalam bagian Pemeriksaan Perkara Pasal 10 pada PERMA tersebut, pada poin (1) disebutkan bahwa:

(1) Pada hari sidang pertama, Pemohon wajib menghadirkan:

a. Anak yang dimintakan permohonan Dispensasi Kawin.

b. Calon suami/isteri.

c. Orang Tua/Wali calon suami/isteri.

Selain itu hakim memeriksa bukti-bukti, seperti kedokumenan. Seperti yang tercantum dalam Pasal 5 PERMA tersebut, pada bagian persyaratan adminstrasi mencakup:

a. Surat permohonan

b. Fotokopi Kartu Tanda Penduduk kedua Orang Tua/Wali;

c. Fotokopi Kartu Keluarga;

d. Fotokopi Kartu Tanda Penduduk atau Kartu Identitas Anak dan/atau akta kelahiran Anak;

e. Fotokopi Kartu Tanda Penduduk atau Kartu Identitas Anak dan/atau akta kelahiran calon suami/istri; dan

f. Fotokopi ijazah Pendidikan terakhir anak dan/atau Surat Keterangan Masih Sekolah dari Sekolah Anak.

Setelah dilihat dari kelengkapan atas dokumen atau bukti-bukti administrasi tersebut, Hakim pun menelaah dan mempertimbangkan pada perkara tersebut apakah yang membutuhkan izin atas dispensasi tersebut hanya salah satu pihak dari calon mempelai atau apakah dari kedua belah pihak ini juga membutuhkan izin dispensasi. Hakim pun dalam memutus pemberian dispensasi ini dapat meminta rekomendasi dari lembagalembaga terkait, contohnya seperti lembaga Pusat Pelayanan Terpadu Perlindungan Perempuan dan Anak (P2TP2A) dengan sebelumnya para 
pemohon yang berkonsultasi terlebih dahulu pada lembaga P2TP2A tersebut. Seperti yang terdapat dalam PERMA Pasal 15 butir d, disebutkan bahwa dalam memeriksa Anak yang dimohonkan dispensasi perkawinan, hakim dapat:

"Meminta rekomendasi dari Psikolog atau Dokter/Bidan, pekerja Sosial Profesional, Tenaga Kesejahteraan Sosial, Pusat Pelayanan Terpadu Perlindungan Perempuan dan Anak (P2TP2A), Komisi Perlindungan Anak Indonesia/Daerah (KPAI/KPAD)”.

Selanjutnya rekomendasi tersebut tertuang dalam bentuk Surat Rekomendasi. Surat rekomendasi tersebut menjadi bahan untuk pertimbangan dan masukkan untuk hakim dalam memutus apakah akan dikabulkan atau ditolak permohonan didpensasi perkawinan tersebut. Berdasarkan wawancara bersama hakim, sepanjang penelitian ini pada pada Pasal 15 tersebut jika dilihat secara urgensinya, dalam memutus perkara permohonan dispensasi perkawinan di Sukabumi ini hakim belum memakai kebolehan tersebut karena dirasa para hakim masih menanganinya dengan sendiri atau belum membutuhkan rekomendasi tersebut.

Secara garis besar, di pengadilan agama sukabumi terdapat beberapa bentuk penetapan mengenai dispensasi perkawinan ini, Pertama dispensasi diberikan kepada calon mempelai wanita yang umurnya masih di bawah batas minimum untuk melangsungkan perkawinan. Kedua, dispensasi diberikan kepada calon mempelai pria yang umurnya masih di bawah batas minimum usia untuk melangsungkan perkawinan. Ketiga, pemberian dispensasi perkawinan kepada perempuan di bawah umur yang sudah hamil. Keempat, penolakan atau tidak dikabulkannya suatu permohonan dispensasi perkawinan.

Tetapi pada poin keempat, jarang sekali diberikan oleh Hakim pengadilan agama sukabumi. Penolakkan tersebut terjadi apabila hakim menilai adanya indikasi pemaksaan atau tekanan dari orang tua atau pihak lain kepada kedua calon mempelai. Maka kemungkinan besar perkara tersebut akan ditolak. Tetapi sejauh ini, perkara yang terdaftar dan masuk 
ke pengadilan agama Sukabumi tidak ada indikasi yang menunjukkan keterpaksaan dari kedua pihak calon mempelai, tidak ada pula tekanan dari pihak orang tua. Hakim pun menilai, dengan adanya permohonan atau pengajuan permohonan dispensasi tersebut ke pengadilan, menjadi salah satu upaya untuk meminimalisir adanya peristiwa-peristiwa seperti itu, dikarenakan setiap perkara yang masuk ke Pengadilan Agama sudah menjadi kewajiban seorang hakim untuk memeriksa dan mengadilinya. Tentunya, hakim pun bisa menilai apakah dalam perkara tersebut ada gejala atau indikasi peristiwa-peristiwa tersebut.

Pertimbangan hakim lainnya yaitu pada calon mempelai wanita yang mengajukan dispensasi karena umurnya belum mencapai batas terendah usia untuk melangsungkan perkawinan. Berdasarkan wawancara, hakim memaparkan bahwa penilaian hakim untuk memberikan dispensasi kepada wanita yaitu dengan melihat apakah seorang wanita tersebut sudah baligh yang dikatakan sudah baligh ialah wanita berusia 9 tahun dan sudah menstruasi. Hakim memaparkan bahwa jika wanita tersebut sudah menstruasi, secara kesiapan fisiknya sudah dianggap mampu untuk dibuahi dan memiliki keturunan. Faktor lainnya, yaitu dilihat dari kesiapan mental atau secara psikis. Mengenai kesiapan mental dan psikis, anak-anak yang telah berusia pada 19 tahun diyakini mampu dan memungkinkan mempunyai kesiapan mental dan psikis yang dinilai sudah cukup matang. Maka dengan keyakinannya, hakim bisa saja mengabulkan dan memberikan izin dispensasi kepada para pemohon. Faktor lain yang melatar belakanginya yaitu karena Hakim berkeyakinan, bahwa calon pengantin pria sudah cukup layak atau siap menjalankan kewajibannya sebagai seorang suami atau seorang ayah secara mental dan fisiknya, dan telah cukup layak untuk menjadi seorang kepala rumah tangga yang bertanggung jawab. Apabila permohonan ini ditujukan dengan tujuan mendapatkan dispensasi karena calon mempelai pria belum cukup umur untuk melangsungkan perkawinan. 
Seorang hakim juga perlu mempertimbangkan mengenai kesiapan finansial calon mempelai, jika dirasa calon mempelai pria belum mempunyai kesiapan untuk menafkahi dengan cukup calon istrinya, tetapi orang tua atau keluarga bersedia untuk mendukung secara moril dan materiil dikarenakan kondisi orang tua berada dalam kondisi ekonomi yang lebih dari cukup. Dengan keinginan orang tuanya tersebut, biasanya tidak dapat ditolak. Seperti yang tercantum dalam Pasal 3 Undang-Undang Nomor 23 Tahun 2002 tentang Perlindungan Anak, pada pasal tersebut dinyatakan bahwa tujuan dari perlindungan anak itu adalah untuk mewujudkan anak Indonesia yang berkualitas, berakhlak mulia, dan sejahtera. Dengan adanya Undang-undang ini, maka menjadi suatu jaminan untuk anak-anak dengan terwujudnya kehidupan yang layak dan ideal bagi anak tetapi bukan untuk melegitimasi semua kehendak anak yang diluar batas kewajaran, termasuk juga keinginan untuk segera melangsungkan perkawinan di usia anak-anak. ${ }^{6}$

Pertimbangan hakim lainnya yaitu dengan memberikan dispensasi kepada anak yang sudah hamil. Pada perkara ini, hakim pengadilan agama sukabumi tidak jarang pula memberikan izin untuk melangsungkan perkawinan. Berdasarkan hasil wawancara, hakim mengemukakan bahwa dasar diberikannya izin pada perkara ini adalah dengan mempertimbangkan akibat hukumnya anak yang telah dikandung tersebut. Jika melihat dari pasal 53 Kompilasi Hukum Islam, pada pasal tersebut disebutkan bahwa:

(1) Seorang wanita hamil di luar nikah, dapat dikawinkan dengan pria yang menghamilinya.

(2) Perkawinan dengan wanita hamil yang disebut pada ayat (1) dapat dilangsungkan tanpa menunggu lebih dahulu kelahiran anaknya

${ }^{6}$ Suadi. 
(3) Dengan dilangsungkannya perkawinan pada saat wanita hamil, tidak diperlukan perkawinan ulang setelah anak yang dikandung lahir. ${ }^{7}$

Jika dilihat dari Kompilasi Hukum Islam, maka hukum melakukan kawin hamil dianggap bisa. Jika dilihat dari pendapat hakim dalam memberikan dispensasi kepada wanita yang sudah hamil ini guna sebagai salah satu asas kebolehan kawin hamil. Pemberian izin ini, dengan maksud hakim unttuk memberikan perlindungan hukum yang pasti kepada anak dalam kandungan. ${ }^{8}$ Disamping itu semua sebagai tindakan preventif dari pengadilan itu sendiri, pada Pasal 12 PERMA tersebut disebutkan bahwa:

(1) Hakim dalam persidangan harus memberikan nasihat kepada Pemohon, Anak, Calon Suami/Isteri dan Orang Tua/Wali Calon Suami/Isteri dan Orang Tua/Wali Calon suami/Isteri.

(2) Nasihat yang disampaikan oleh Hakim, untuk memastikan Orang Tua, Anak, Calon Suami/Isteri dan Orang Tua/Wali Calon Suami/Isteri agar memahami resiko perkawinan, terkait dengan:

a. Kemungkinan berhentinya pendidikan bagi anak;

b. Keberlanjutan anak dalam menempuh wajib belajar 12 tahun;

c. Belum siapnya organ reproduksi anak;

d. Dampak ekonomi, sosial dan psikologis bagi anak; dan

e. Potensi perselisihan dan kekerasan dalam rumah tangga.

Jika dalam prosesnya hakim tidak memberikan nasihat tersebut, maka dalam ayat ke (4) PERMA tersebut disebutkan mengakibatkan penetapan batal demi hukum. Dalam memutus atau memberikan izin

${ }^{7}$ Kompilasi Hukum Islam (Jakarta: Kencana, 2017) Hlm. 17

${ }^{8}$ Mardani, Hukum Keluarga Islam di Indonesia, 2nd edn (Jakarta: Kencana, 2017). Hlm. 
dipensasi perkawinan, hakim juga memakai kaidah fikih, yang berbunyi:

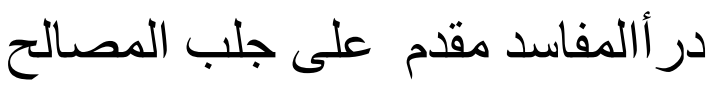

Artinya: “mengambil mafsadat didahulukan daripada mengambil manfaat”

Dengan maksud apabila pada saat itu ada kemaslahatan lebih besar tetapi diiringi dengan mafsadat, maka pada saat itu pilihlah maslahat daripada mafsadat. Seperti halnya dalam memberikan izin dispensasi untuk melangsungkan kawin hamil, terdapat ke mafsadatan dalam perkara ini, tetapi hakim lebih mengambil manfaatnya dengan tujuan menyelamatkan status anak yang dikandung tersebut sebagai anak sah dalam perkawinan. Dengan artian lain hakim mempertimbangkan dengan mengambil kemungkinan terjadinya kemudaratan yang paling terkecil.

\section{Kesimpulan}

Berdasarkan Pasal 10 ayat (1) Undang-Undang Nomor 48 tahun 2009 tentang kekuasaan kehakiman, bahwa dalam memeriksa, mengadili, memutus suatu perkara pengadilan dilarang untuk menolak atas segala perkara yang diajukan, dengan segala dalil hukumnya yang mengatur tidak ada atau kurang jelas, dalam artian lain maka pengadilan wajib untuk memeriksa dan mengadilinya. Utamanya mengenai perkara dispensasi perkawinan ini peraturan perundang-undangannya telah ada dan cukup jelas. Menurut hasil wawancara bersama hakim pengadilan agama Sukabumi, dalam pengabulan perkara dispensasi perkawinan ini juga hampir tinggi setidaknya hampir 90\% perkara yang masuk mendapat pengabulan dan izin untuk melangsungkan perkawinan. Hakim menggunakan PERMA Nomor 5 tahun 2019 tentang Pedoman Mengadili Permohonan Dispensasi Kawin sebagai landasan dalam memutus dan mengabulkan perkara dispensasi perkawinan ini. Di dalam PERMA tersebut terdapat asas-asas yang dijadikan dasar oleh hakim untuk memutus dan mengadili mengenai perkara dispensasi perkawinan. Terdapat beberapa bentuk penetapan mengenai dispensasi perkawinan di pengadilan 
agama sukabumi, diantaranya yaitu dispensasi yang diberikan kepada calon mempelai wanita yang umurnya masih di bawah batas minimum untuk melangsungkan perkawinan, dispensasi yang diberikan kepada calon mempelai pria yang umurnya masih di bawah batas minimum usia untuk melangsungkan perkawinan, pemberian dispensasi perkawinan kepada perempuan di bawah umur yang sudah hamil, penolakan atau tidak dikabulkannya suatu permohonan dispensasi perkawinan. Namun penolakan atau tidak dikabulkannya permohonan dispensasi perkawinan di pengadilan agama sukabumi ini jarang sekali diberikan oleh majelis hakim. 


\section{DAFTAR PUSTAKA}

Ahyani, Sri, 'Pertimbangan Pengadilan Agama Atas Dispensasi Pernikahan Usia Dini Akibat Kehamilan Di Luar Nikah’, Jurnal Wawasan Yuridika, 34.1 (2016), 31

Edi Gunawan, Budi Rahmat Hakim. "Pelaksanaan Itsbat Nikah Pasca Berlakunya UU No. 1 Tahun 1974 Tentang Perkawinan di Pengadilan Agama” Syariah: Jurnal Hukum dan Pemikiran Vol 18, No 2 (2018) http://dx.doi.org/10.18592/sy.v18i2.2319

Elkhairati, Elkhairati, 'Pembatasan Usia Perkawinan (Tinjauan Undang-Undang Dan Maqashid Asy-Syari'ah)', Al-Istinbath: Jurnal Hukum Islam, 3.1 (2018), 87

Fadal, Kurdi. " Pernikahan Di Bawah Umur Perspektif Maqashid Al-Qur'an" Jurnal Hukum Islam [Online], (12 June 2016)

Hadaiyatullah, Syeh Sarip, Nurul Huda, Panitra Pengadilan, Agama Gedong, Tataan Pesawaran, and A Pendahuluan, 'Praktek Hukum Acara Dispensasi Kawin', 2019, 150-68

Herni Widanarti. “Tinjauan Yuridis Terhadap Permohonan Pengesahan Perkawinan Yang Tidak Dicatatkan (Istbat Nikah)” Jurnal MasalahMasalah Hukum Jilid 42, Nomor 2, Tahun 2013 DOI: $10.14710 / \mathrm{mmh} .42 .2 .2013 .172-180$

Imron, Ali, 'Dispensasi Perkawinan Perspektif Perlindungan Anak', Jurnal Ilmiah Ilmu Hukum Qisti2, 5.1 (2011), 87

Kamus Besar Bahasa Indonesia, ke-lima (Bahan Pengembangan Bahasa, Kementerian Pendidikan dan Kebudayaan Republik Indonesia, 2016)

Mardani, Hukum Keluarga Islam Di Indonesia, 2nd edn (jakarta: KENCANA, 2017)

Prabowo, Bagya Agung, 'Pertimbangan Hakim Dalam Penetapan Dispensasi Perkawinan Dini Akibat Hamil Di Luar Nikah Pada Pengadilan Agama Bantul', Jurnal Hukum Ius Quia Iustum, 20.2 (2013), 300-317

Suadi, Amran, Aspek Perlindungan Anak Indonesia: Analisis Tentang Perkawinan Di Bawah Umur (jakarta, 2018) Ahyani, Sri, 'Pertimbangan Pengadilan Agama Atas Dispensasi Pernikahan Usia Dini Akibat Kehamilan Di Luar Nikah’, Jurnal Wawasan Yuridika, 34.1 (2016), 31 
Tinggi, Sekolah, and Agama Islam, 'Prosedur Dan Penyelesaian Dispensasi Nikah Dibawah Umur Di Pengadilan Agama’, 6 (2019), 133-50

Umar, Mukhsin Nyak, Rekonstruksi Pemikiran Hukum Islam Di Indonesia (Banda Aceh: Yayasan PeNA, 2006)

Islamiyati, Islamiyati. "Analisis Putusan Mahkamah Konstitusi No. 68/Puu/Xii/2014 Kaitannya Dengan Nikah Beda Agama Menurut Hukum Islam Di Indonesia" Al-Ahkam [Online], Volume 27 Number 2 (12 October 2017)

Riswan Munthe, Sri Hidayani. "Kajian Yuridis Permohonan Itsbat Nikah Pada Pengadilan Agama Medan” JUPIIS: Jurnal Pendidikan Ilmu-ilmu Sosial Vol 9, No 2 (2017) https://doi.org/10.24114/jupiis.v9i2.8240.g6928

Surur, Ahmad. " Perceraian Dini: Studi Terhadap Putusan Pengadilan Agama Pekalongan Tahun 2013" Jurnal Hukum Islam [Online], (26 January 2017)

Sun Basana Hutagalung, Ferri Aries Suranta, Januari Siregar, "Peranan Hakim Dalam Menyelesaikan Kasus Tindak Kekerasaan Terhadap Perempuan Dan Anak” Jurnal Mercatoria Vol 2, No 1 (2009) https://doi.org/10.31289/mercatoria.v2i1.677

Trigiyatno, Ali. " Pernikahan Dini Di Kalangan Masyarakat Batang" Jurnal Penelitian [Online], Volume 6 Number 1 (21 May 2013) 